Citation: Roblero-Hidalgo, R. Chávez-Morales, J., Ibáñez-Castillo L. A. \& Palacios-Vélez, O. L. (2022) Estimation of water erosion in the Necaxa system, Puebla, Mexico. Agro Productividad. https://doi.org 10.32854/agrop.v15il.2003

Editor in Chief: Dr. Jorge Cadena Iñiguez

Received: April 23, 2021. Accepted: January 12, 2022.

Published on-line: February 5, 2022.

Agro Productividad, 15(1). January. 2022. pp: 87-102.

This work is licensed under a Creative Commons Attribution-NonCommercial 4.0 International license.

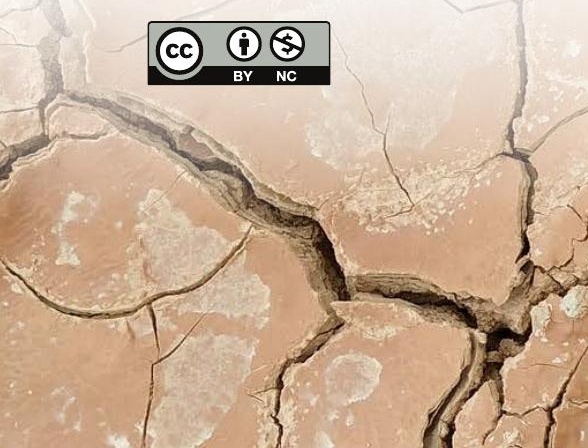

\section{Estimation of water erosion in the Necaxa system, Puebla, Mexico}

\author{
Roblero-Hidalgo, Rodrigo ${ }^{1}$; Chávez-Morales, Jesús ${ }^{2 *}$; Ibáñez-Castillo Laura A. ${ }^{3}$ \\ Palacios-Vélez, Oscar L. ${ }^{4}$ \\ 1 Instituto Mexicano de Tecnología del Agua, Progreso, Jiutepec, Morelos, México, C.P. 62550. \\ 2 Colegio de Postgraduados, Campus Montecillo, Montecillo, Texcoco, Estado de México, México, C.P. \\ 56230. \\ 3 Universidad Autónoma Chapingo, Chapingo, Estado de México, México, C.P. 56230. \\ 4 Colegio de Postgraduados, Campus Montecillo, Montecillo, Texcoco, Estado de México, México, G. P. \\ 56230. \\ * Correspondence: chavezje@colpos.mx
}

\section{ABSTRACT}

Objective: To estimate the potential and current water erosion in the Necaxa system and to propose alternatives aimed to reduce the siltation problem in the hydraulic infrastructure.

Design/methodology/approach: The Universal Soil Loss Equation (USLE) was applied, using a Geographic Information System to process the map algebra.

Results: The current estimated water erosion was $159 \mathrm{t} \mathrm{ha}^{-1}$ per year; this factor impacts the loss of farmland and soil nutrients, the accumulation of matter towards urban areas, the siltation of riverbeds and dams, and the loss of the system's hydraulic works capacity.

Study limitations/implications: No data about runoff plots in the field is available; therefore, it is not possible to compare current water erosion values with those obtained by the USLE applied, using the map algebra technique.

Findings/conclusions: The reforestation and conservation agriculture proposal would help to reduce erosion to $16 \mathrm{tha}^{-1}$ per year. However, if control actions are not carried out and the current vegetation cover is not preserved, the problem can increase until it reaches potential erosion values $>200 \mathrm{t} \mathrm{ha}^{-1}$ per year.

Keywords: erosion, basin management, map algebra.

\section{INTRODUCTION}

The United States Department of Agriculture (USDA) has been carrying out researches about water erosion and applying soil loss quantification models since the middle of the 19th century; the USDA analyzed the effects of different vegetable covers and crop rotation on the surface runoff and the erosion in experimental runoff plots (Oropeza Mota, 2007).

In 1935, with the creation of the Soil Conservation Services, the USDA started their studies about the mechanics of the erosion processes. These studies included the research about the raindrop impact on bare soil (splash erosion), which enabled the establishment of the first models used to estimate the soil loss caused by water erosion. In Mexico, similar studies started in 1970 by the Área de Física de Suelos of the Colegio de Postgraduados 
(currently, the postgraduate department of Edaphology). In the basin of the Texcoco River, $50-\mathrm{m}^{2}$ experimental plots with different soil uses were established for this purpose (Oropeza Mota, 2007).

In 1958, Wischmeier and Smith (1978) developed the USLE using erosion production mathematical models. The USLE was aimed to predict the average soil loss in agricultural plots, under different farming systems, handling practices, soil types, precipitation patterns, and topography. The USLE application allowed to estimate crop soil loss, soil nutrients loss, drag and accumulation of matter towards urban areas, siltation of riverbeds and dams, and the loss of hydraulic works capacity (Montes-León et al., 2011).

Studies about erosion have been carried out in other countries and regions, including: Argentina (Rodríguez-Vagaría and Gaspari, 2015; Olmos et al., 2008); Spain (LozanoGarcía and Parras-Alcántara, 2011); Africa (Dumas, 2012); Guatemala (Luna Lemus, 2016); Morocco (Saldaña Días et al., 2014); Venezuela (Pacheco Gil, 2012); Chile (Bonilla et al., 2010; Muñoz-Marcillo et al., 2014; Laval Molkenbuhr, 2009; and Pizarro et al., 2009); Central Greece (Stefanidis et al., 2017); Haiti (Morales Ascarrunz, 2014);and Peru (Jiménez Callejo et al., 2008; Díaz R., 2015; and Portuguez M., 2015).

In Mexico, the main erosion studies have been carried out in the following states: Chihuahua (Alatorre et al., 2014); Veracruz (Melchor-Marroquín and Chagoya-Fuentes, 2016); Tabasco (Río Grijalva basin) (Zavala-Cruz et al., 2011); Durango (López-Santos et al., 2012); Durango, Zacatecas, Sonora, Chiapas, and Tabasco (Flores Islas, 2016); San Luis Potosí (Durán Trejo, 2012); Jalisco (Flores-López et al., 2002; and Torres Benites et al., 2003); Querétaro (Alejandrina et al., 2013); and Estado de México (Pedraza Villafaña, 2015). Montes-León et al. (2011) developed a national map of potential erosion in Mexico. The objective of this study is to calculate the potential and current erosion and control alternatives, based on land use change and soil conservation practices in the basins that make up the Necaxa system, in northern Puebla, Mexico.

\section{MATERIALS AND METHODS}

The study was carried out in the $\mathrm{X}$ hydrological-administrative region (Golfo Centro), 27th Hydrological Region (Tuxpan-Nautla). The following sub-basins were analyzed: the San Marcos River $\left(1,635 \mathrm{~km}^{2}\right)$ in the Cazones River basin and the Necaxa River $\left(900 \mathrm{~km}^{2}\right)$ and the Laxaxalpan River $\left(1,608 \mathrm{~km}^{2}\right)$ in the Tecolutla River basin (Figures 1 and 2).

The following dams can be found in the hydrological system of the study sub-basins: Los Reyes, Laguna, Nexapa, Tenango, and Necaxa (Figure 3).

\section{Collected data}

- Digital Elevation Model (DEM), with a 15-m pixel resolution, 1:50,000 scale (INEGI, 2013).

- Edaphological, series II, 1:250,000 scale (INEGI, 2007).

- Land use and vegetation, VI, 1:250,000 scale (INEGI, 2003).

- Average annual precipitation of the Extractor Rápido de Información Climatológica, ERIC III (SMN, 2017). 


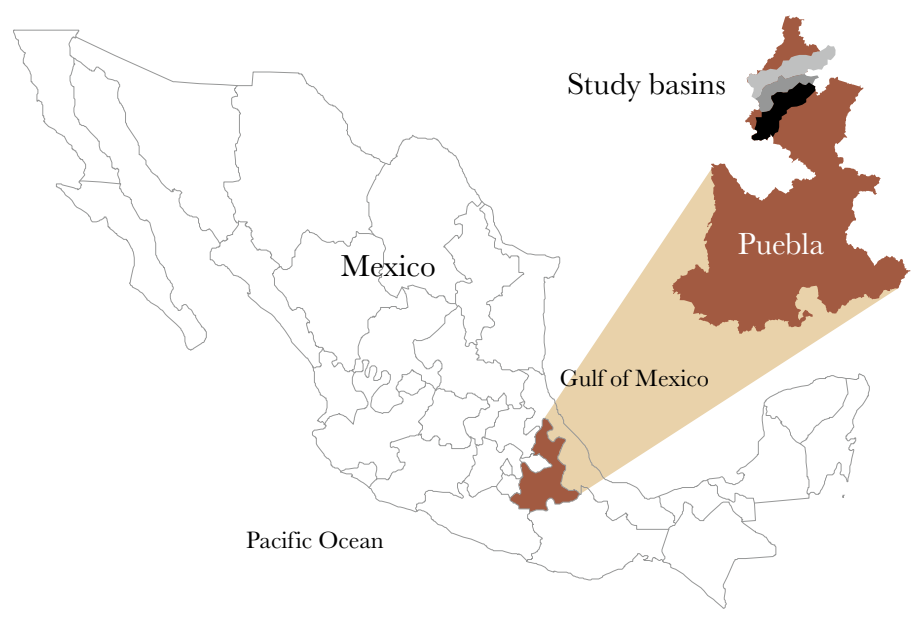

Figure 1. Location of the sub-basins of the San Marcos, Necaxa, and Laxaxalpan rivers.

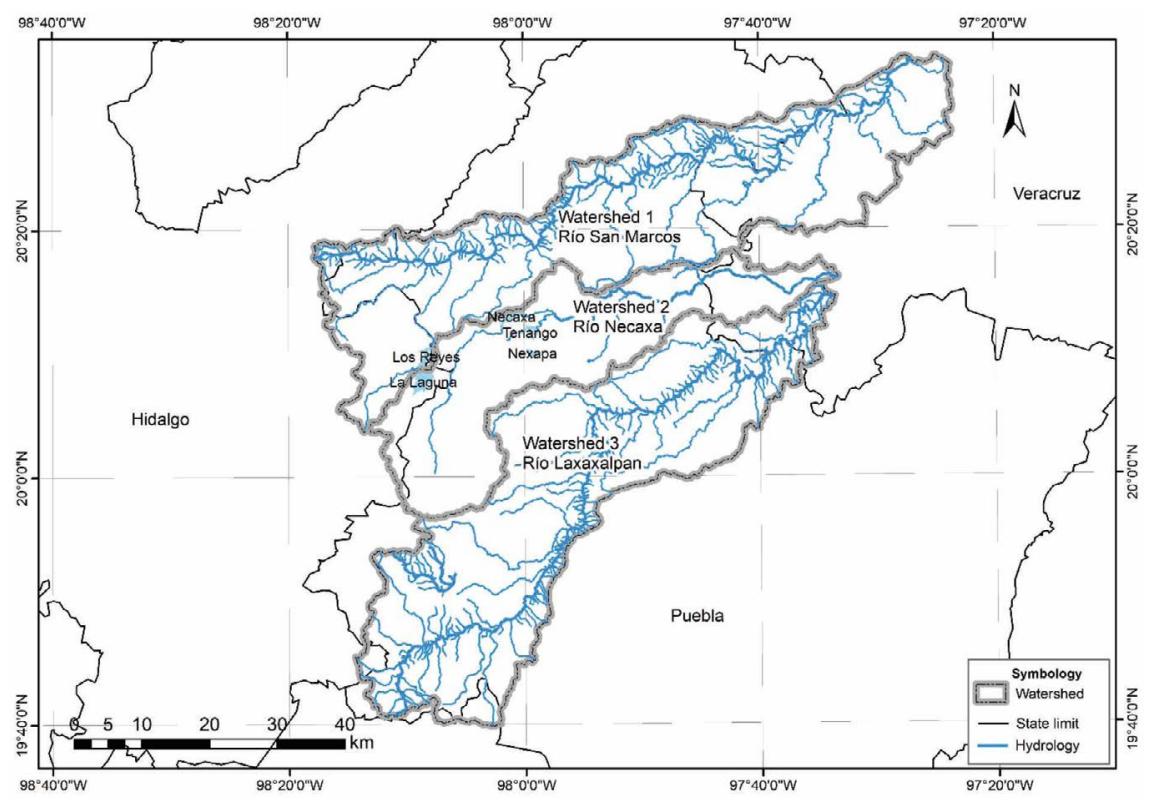

Figure 2. Hydrology of the sub-basins of the San Marcos, Necaxa, and Laxaxalpan rivers.

The USLE proposed by Wischmeier \& Smith (1978) was used to determine hydric erosion:

$$
A=R * K * L * S * C * P
$$

Where: $A=$ Average annual soil loss (ton/ha*year); $R=$ Rainfall erosivity $\left(\mathrm{MJ}^{*} \mathrm{~mm} / \mathrm{ha}{ }^{*} \mathrm{~h}\right.$ ); $K=$ Soil erodibility factor (ton*ha/MJ*mm); $L=$ Slope length gradient factor(Dimensionless); $S=$ Slope inclination gradient factor (Dimensionless); $C=$ Cover Management Factor (Dimensionless); $P=$ Support Practice Factor (Dimensionless). 


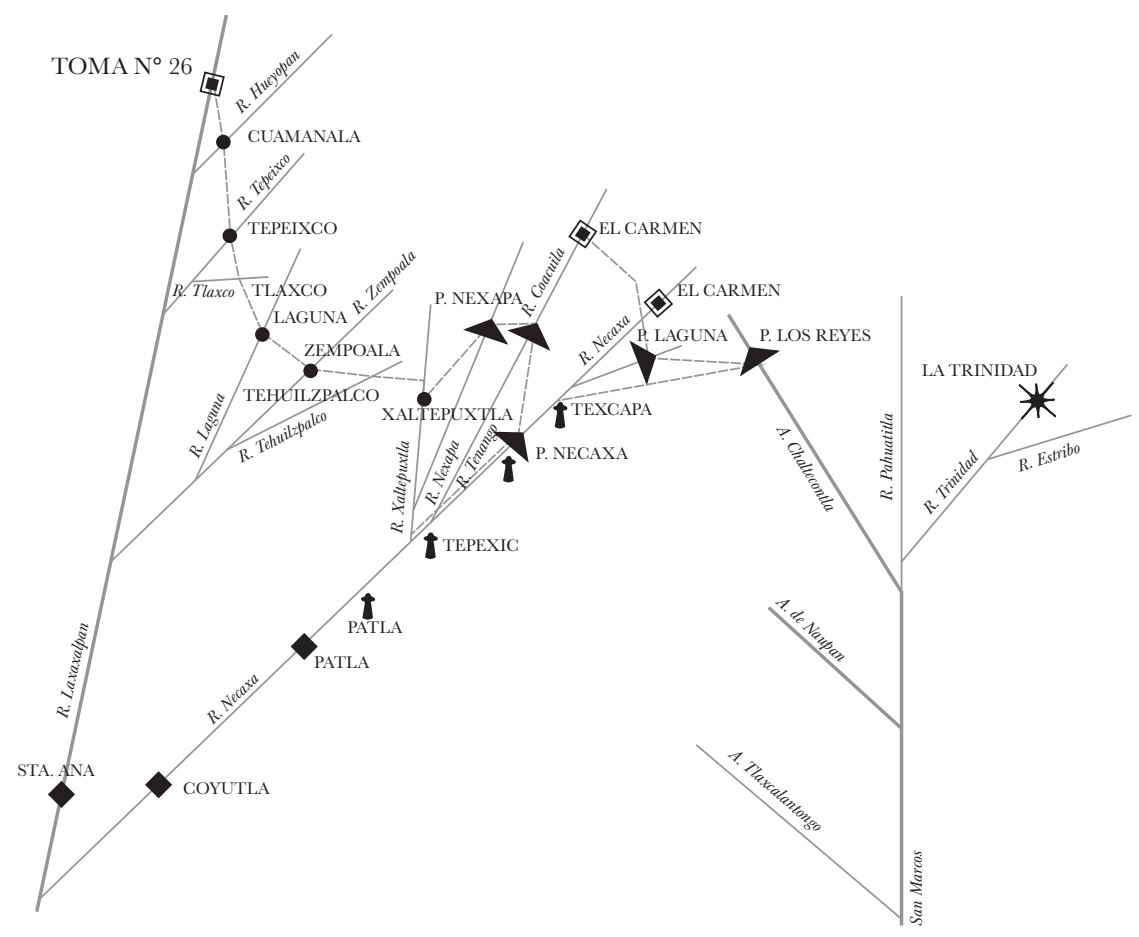

Figure 3. Linear diagram of the dams of the Necaxa system (SRH, 1969).

\section{Rainfall runoff erosivity factor $(\mathbf{R})$}

The R-factor is related to the weather factor and represents the potential energy of the rainfall produced by a storm when it reaches its maximum intensity in $30 \mathrm{~m}$. The method proposed for Mexico by Becerra (2017, quoted by Montes-León et al. (2011)) was used, selecting Region 9.

$$
R=7.0458 * P-0.002096 * P^{2}(2)
$$

Where: $P=$ is the average annual precipitation $(\mathrm{mm})$.

The average annual precipitation $(\mathrm{P})$ data was obtained from the ERIC III data base, which includes 97 stations within and nearby the study area (SMN, 2017). Forty-four stations met the criteria: $20+$ years and $80 \%$ of available data.

Using the geographical coordinates (Long. $\mathrm{X}$ and Lat. $\mathrm{Y}$ ) and the $\mathrm{P}$ values, a raster model was created for each station, using R-factor interpolated data, from the vectorial factor (*.shp), ArcGIS (ESRI, 2016), Figure 4.

\section{Soil Erodibility Factor $(\mathbf{K})$}

The term "soil erodibility" indicates the susceptibility of a given soil to erosion. The $\mathrm{K}$-factor indicates the said susceptibility degree and is defined based on the characteristics of the soil: texture, organic matter content, structure, and permeability.

The edaphological data of the series II maps (INEGI, 2007) includes the type of soils and textures. Based on this information, the method proposed by the Food and Agriculture 


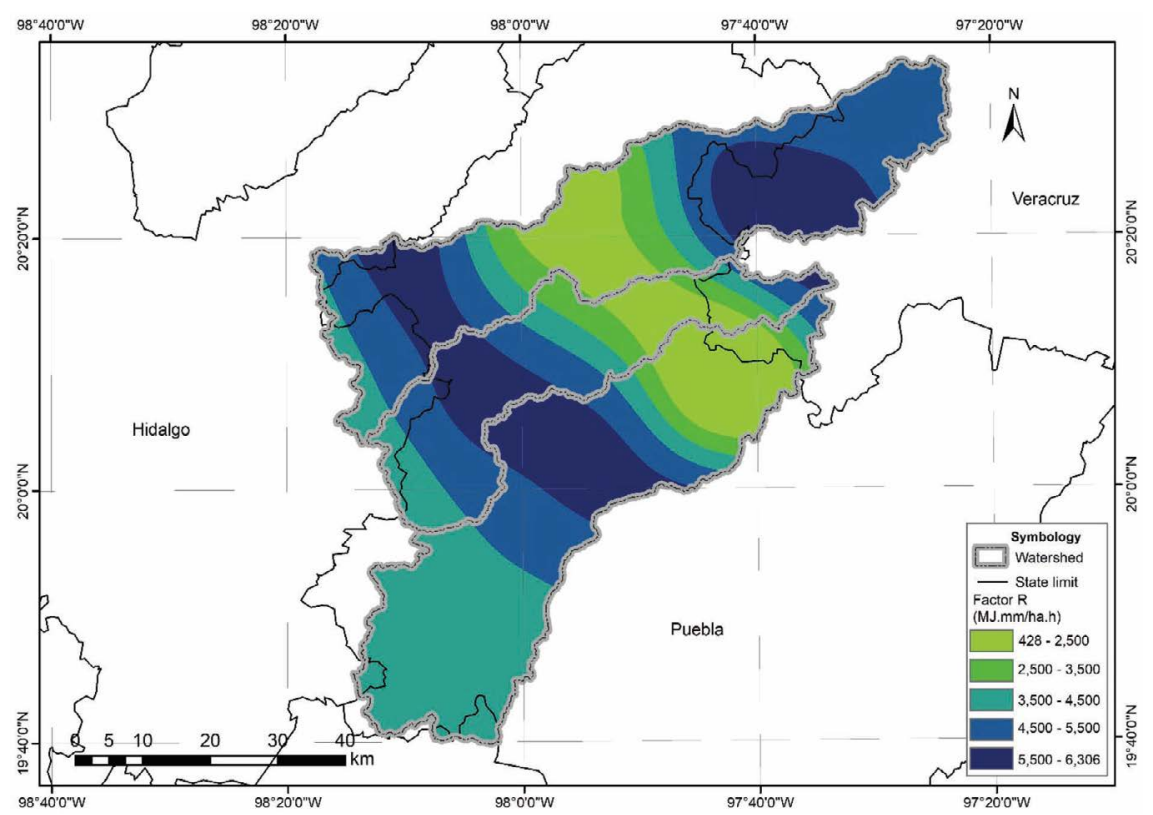

Figure 4. Spatial distribution of the R-factor. The Erosivity values $(\mathrm{R})$ range from 428 to $6,306 \mathrm{MJ}{ }^{*} \mathrm{~mm} /$ $\mathrm{ha}^{-1} \mathrm{~h}^{-1}$; the lower values of the analyzed basins can be found in the middle strip.

Organization (FAO) (FAO, 2015) was used to determine the K-factor. The $\mathrm{K}$ values $\left(\mathrm{t} \mathrm{h}^{-1}\right.$ / $\mathrm{MJ}^{-1} \mathrm{~mm}$ ) were assigned based on this data (presented in a vectorial format (*.shp)). This information can be found in Table 1 .

The minimum K values (0.007) match Nitisol and Phaeozem which are fine-textured soil types. The maximum K-factor value (0.079) matches the medium-textured Durisol. Based on this vectorial data (*.shp), a raster model (*.tif) was generated, using the interpolated $\mathrm{K}$ values, Figure 5.

Table 1. K-factor values for each type of soil in the study area.

\begin{tabular}{l|c|c|c|c}
\multirow{2}{*}{ Type of soil } & \multirow{2}{*}{ Order } & \multicolumn{3}{c}{ Texture } \\
\cline { 4 - 5 } & & Heavy & Medium & Fine \\
\hline Acrisol & AC & & 0.04 & 0.013 \\
\hline Andosol & AN & & 0.04 & \\
\hline Cambisol & CM & & 0.04 & \\
\hline Durisol & DU & & 0.079 & \\
\hline Fluvisol & FL & 0.026 & & \\
\hline Kastanozem & KS & & & 0.013 \\
\hline Leptosol & LP & & 0.02 & \\
\hline Luvisol & LV & & 0.04 & 0.013 \\
\hline Nitisol & NT & & & 0.007 \\
\hline Phaeozem & PH & & 0.02 & 0.007 \\
\hline Planosol & PL & & & 0.026 \\
\hline Regosol & RG & & 0.04 & \\
\hline Umbrisol & UM & & 0.04 & \\
\hline Vertisol & VR & & & 0.026 \\
\hline
\end{tabular}




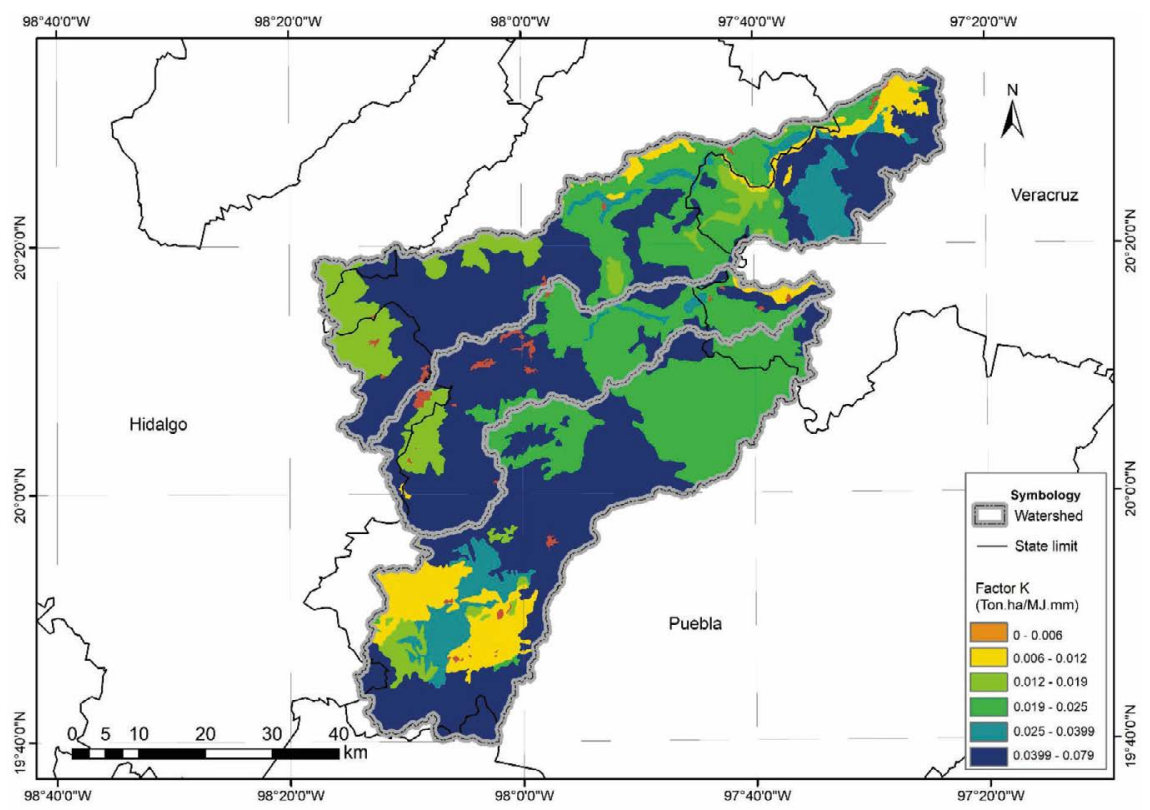

Figure 5. K-factor distribution.

The higher values of $\mathrm{K}$ can be found in the high parts of the basins, while the lower values can be found in the low parts (Figure 5).

\section{Slope length gradient factor $(\mathrm{L})$}

This factor is defined as the distance between the point where the runoff originates and any other point where the slope diminishes, promoting sediment deposition; or between the origin point and the point where the runoff water enters in a well-defined channel, which can be part of a stream network or a built interception channel (e.g., a diversion channel). The L-factor is calculated using the Geographic Information System proposed by Desmet and Gover (Luna Lemus, 2016):

$$
L_{(i, j)}=\frac{\left[A_{(i, j)}+D^{2}\right]^{(m+1)}-A_{(i, j)}{ }^{(m+1)}}{x^{m} * D^{m+2} *\left(22.13^{m}\right)}
$$

Where: $L=$ Slope length gradient factor, dimensionless. $i=x$-direction index, from $i=1$, $2, \ldots$, limit, number of pixels in $x, j=y$-direction index, from $j=1,2, \ldots$, limit number of pixels in $y . A=$ Unit Contributing Area of each pixel, $\mathrm{m}^{2} . D=$ Side of each pixel, $\mathrm{m}$. $x=$ Form coefficient $(x=1$ for pixel systems). $m=$ Coefficient dependent on the slope-length interactions, calculated as follows:

$$
m=\frac{F}{1+F}
$$

$F$ is calculated according to the following formula: 


$$
F=\frac{\sin \beta / 0.0896}{3 *(\sin \beta)^{0.8}+0.56}
$$

Where: $\beta=$ Slope at each pixel level (expressed in radians; radians to degrees conversion factor: 0.01745), radians.

The SIG ArcGis software (ESRI, 2016) was used to calculate equations (3), (4), and (5), based on the digital elevation model (DEM).

Based on the visualization of the properties of the raster model of the DEM, the value obtained is $\mathrm{D}=15.203 \mathrm{~m}$, which matches the length of each pixel.

The value factor $L_{(i, j)}$ was calculated using all these elements.

\section{Slope length gradient factor $(\mathrm{S})$}

The S-factor was calculated using the methodology proposed by Renard (Montes-León et al., 2011), where two conditions on the slope are analyzed. It is expressed as:

$$
\begin{array}{ll}
\tan \beta_{(i, j)}<0.09 & S_{(i, j)}=10.8 * \sin \beta_{(i, j)}+0.03 \\
\tan \beta_{(i, j)} \geq 0.09 & S_{(i, j)}=16.8 * \sin \beta_{(i, j)}-0.50
\end{array}
$$

The DEM and the SIG ArcGis software(ESRI, 2016) were used to obtain the S-factor for the abovementioned conditions; when all the above mentioned conditions are introduced, the layer-factor $S_{(i, j)}$ is obtained.

Subsequently, using the $L_{(i, j)}$ and $S_{(i, j)}$ rasters, the following multiplication was carried out, $L_{(i, j)} * S_{(i, j)}$, Figure 6.

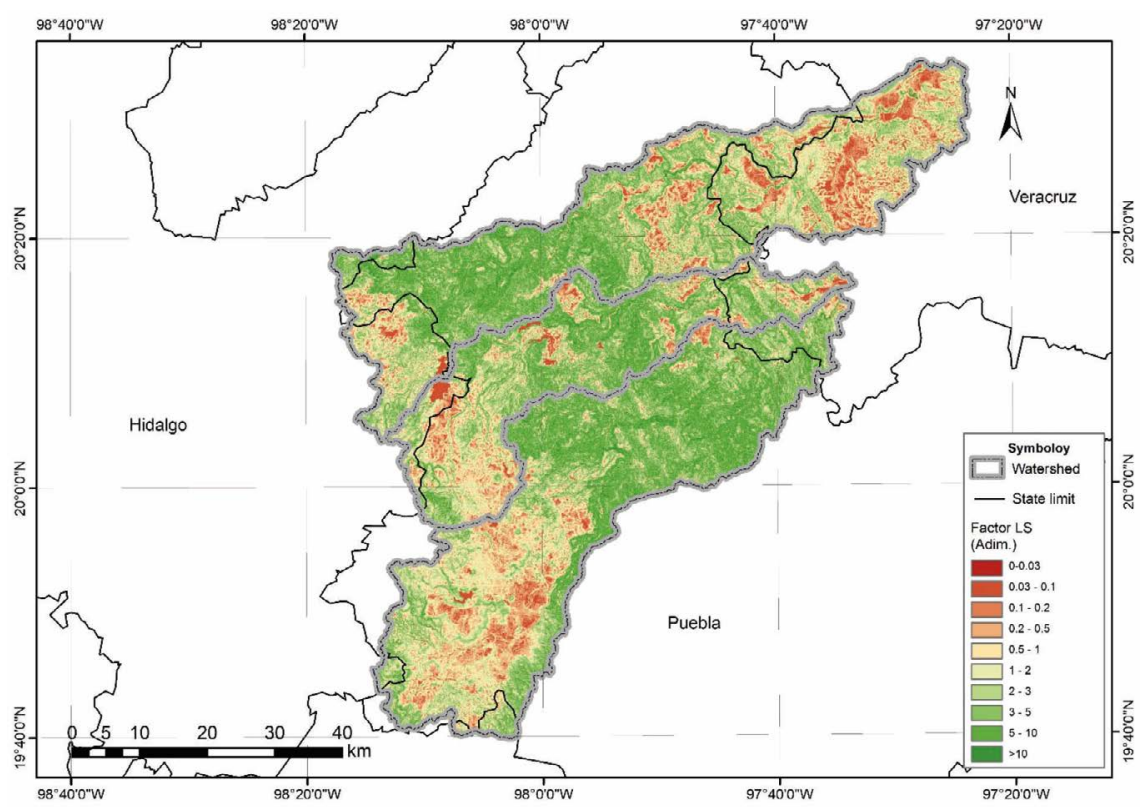

Figure 6. Distribution of the $L_{(i, j)} * S_{(i, j)}$ factors. 
The highest LS values were obtained in the central part of the basins, while the lowest values were found at the basin exit, mainly in the sub-basin of the San Marcos River.

\section{Cover Management Factor $(\mathbf{C})$}

The $\mathrm{G}$-factor measures the combined effect of vegetal cover and handling practices on the erosion rates. This factor is the main element to plan soil conservation and to calculate how these covers can eventually impact soil recovery. This factor ranges from 0 to 1 (1: plots without cover; 0 : completely covered plots). In order to assign a value to $\mathrm{C}$, the table developed by Montes-León (2011) was used, along with the land use and vegetation vectorial layer, series VI; the vectorial, polygon-shaped file was transformed into a raster format (Figure 7).

The main land use and vegetation that prevails in the sub-basins belong to the annual rainfed agriculture type; vegetation covers $22.3 \%$ of the study area, with a $\mathrm{C}$ value of $\mathrm{C}=0.75$.

\section{Support Practices Factor $(\mathbf{P})$}

Mechanical practices are frequently used in farmlands that have $>2 \%$ slopes, to control water erosion and surface runoff, as well as to preserve the soil. The most important mechanical practices are contour furrows, strip cropping, and terraces systems parallel to the contours.

The USLE's P-factor is defined as the ratio of the soil loss under a conservation practice to the soil loss without such conservation practice when the crops are established in the same direction of the slope. The superficial roughness created by tilling, sowing, and farming, as well as other mechanical treatments directed to the level curves seek to reduce erosion. The assessment of the P-factor includes the following support practices: contours

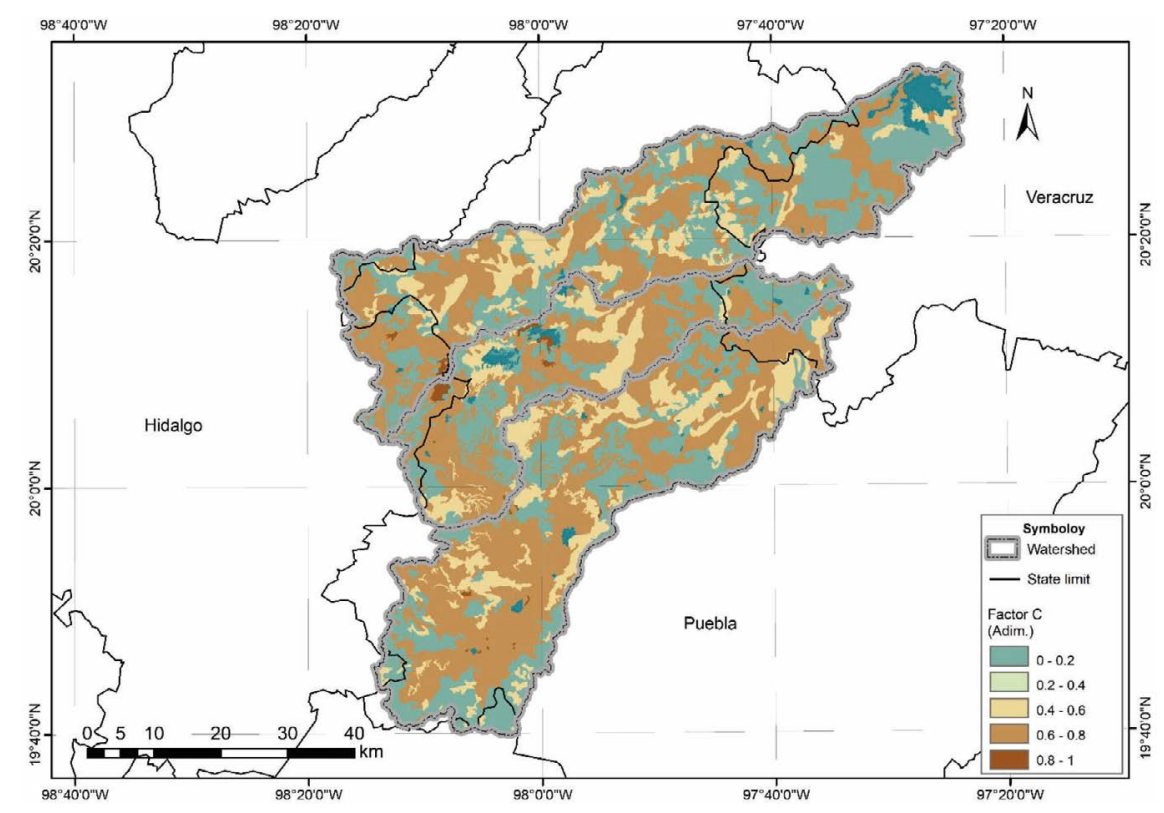

Figure 7. G-factor distribution. 
furrows (tilling, sowing, farming), strip cropping, terraces, and superficial drainage. Factor 1 means that no conservation practices were carried out in the area; therefore, mechanical practices do not reduce erosion.

\section{RESULTS AND DISGUSSION}

Potential erosion, Ap. The ArcGIS (ESRI, 2016) software was used to process the $A p=R * K * L * S$ factors data of equation (1) and the product of the Figures $4 * 5 * 6$, obtaining the potential t ha-1 erosion per year (Figure 8 ). The prevailing erosion values in the study area exceeded $200 \mathrm{t} \mathrm{ha}^{-1}$ per year, distributed in a central strip of the basins.

Gurrent erosion, Aa. Equation $1, A p=R * K^{*} L * S * C * P$ (the product of Figures $4 * 5 * 6 * 7)$ was applied to obtain the current erosion; $\mathrm{P}=1$ was taken into consideration, given that there are no support conservation practices (Figure 9).

When estimating the average potential and current erosion for each sub-basin, we observed that the average erosion would range from 187 to $>200 \mathrm{t} \mathrm{ha}^{-1}$ per year, if there were no cover in the sub-basins surface (Table 2). According to the classification of Table 2 and compared with the national map developed by Montes-León et al. (2011), we can observe that the sub-basins erosion is intense or very high, just like the values reported by UNESCO - PHI (2017). Additionally, Colín-García et al. (2013) obtained similar values for a basin influenced by the Gulf area, with losses between 10 and $200 \mathrm{t} \mathrm{ha}^{-1}$ per year. We also took into consideration the values obtained by Montes-León et al. (2011), which were higher than $200 \mathrm{t} \mathrm{ha}^{-1}$. The highest potential erosion is located in the sub-basins of the middle part of the Necaxa system (Figure 9).

In order to analyze the current erosion of the San Marcos sub-basin, we observed an intense erosion with a soil loss higher than $200 \mathrm{t} \mathrm{ha}^{-1}$ per year in an area of $423.08 \mathrm{~km}^{2}$

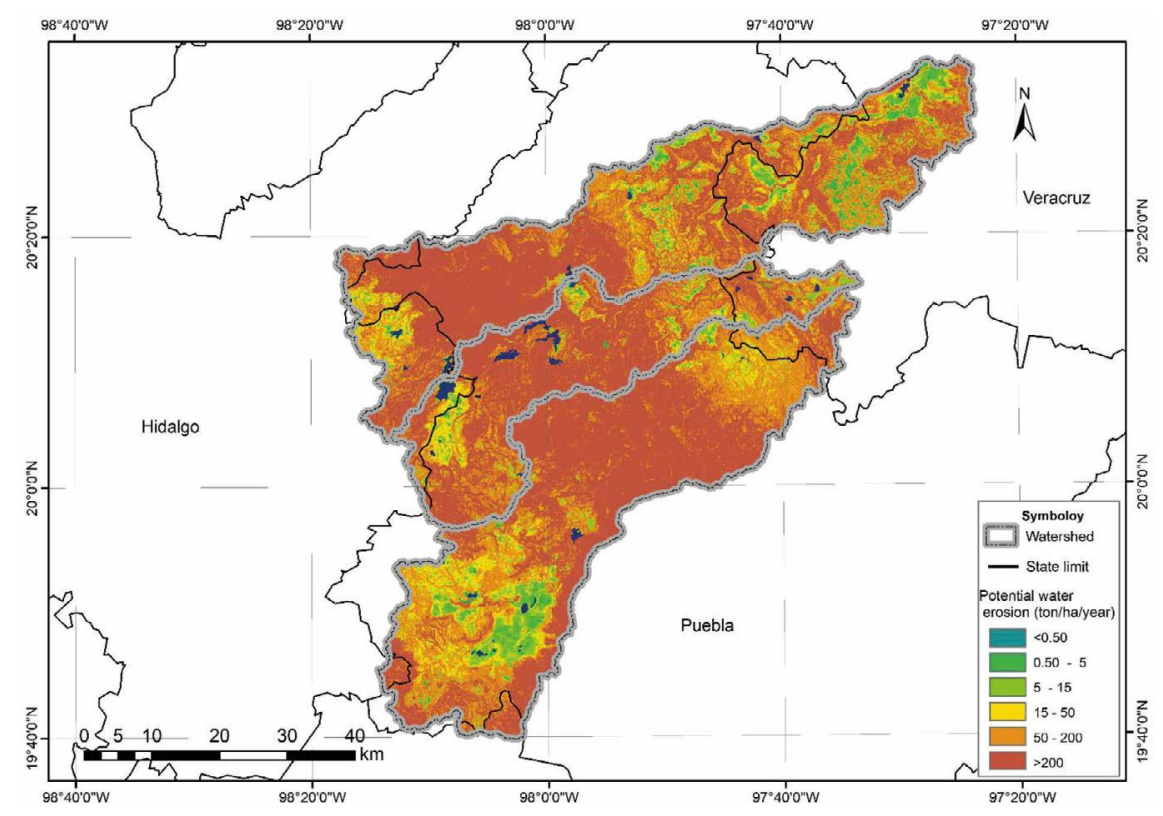

Figure 8. Potential water erosion (ton/ha/year). 


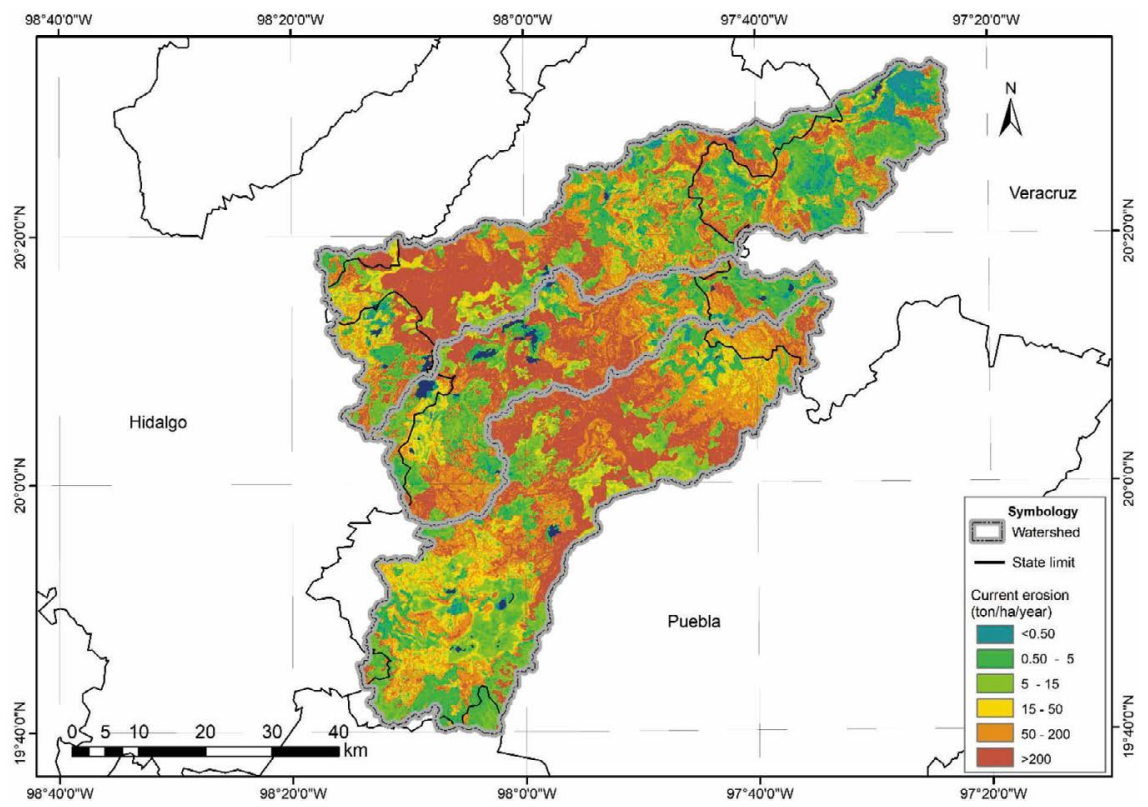

Figure 9. Current erosion (ton/ha/year).

(25.89\%). If the current handling remains unmodified, the potential erosion will increase, reaching an area of $852.71 \mathrm{~km}^{2}(52.17 \%)$ : a surface increase of $26.28 \%$ (Table 2).

Table 2. Potential and current erosion of the sub-basins.

\begin{tabular}{|c|c|c|c|c|c|c|}
\hline \multirow{2}{*}{ Sub-basins } & \multirow{2}{*}{$\begin{array}{c}\text { Erosion range } \\
\text { t ha }^{-1} \text { year }\end{array}$} & \multirow{2}{*}{ Class } & \multicolumn{2}{|c|}{ Potential erosion area } & \multicolumn{2}{|c|}{ Current erosion area } \\
\hline & & & $\mathbf{k m}^{2}$ & $\%$ & $\mathbf{k m}^{2}$ & $\%$ \\
\hline \multirow{6}{*}{ Río San Marcos } & $<0.5$ & Normal & 11.48 & 0.70 & 119.39 & 7.31 \\
\hline & $0.5-5$ & Light & 65.07 & 3.98 & 343.54 & 21.02 \\
\hline & $5-15$ & Moderate & 64.46 & 3.94 & 219.45 & 13.43 \\
\hline & $15-50$ & Severe & 177.91 & 10.88 & 211.48 & 12.94 \\
\hline & $50-200$ & Very severe & 462.91 & 28.32 & 317.12 & 19.41 \\
\hline & $>200$ & Intense & 852.71 & 52.17 & 423.08 & 25.89 \\
\hline \multirow{6}{*}{ Río Necaxa } & $<0.5$ & Normal & 20.22 & 2.25 & 47.64 & 5.29 \\
\hline & $0.5-5$ & Light & 16.32 & 1.81 & 160.01 & 17.77 \\
\hline & $5-15$ & Moderate & 23.72 & 2.63 & 113.46 & 12.60 \\
\hline & $15-50$ & Severe & 78.26 & 8.69 & 95.59 & 10.62 \\
\hline & $50-200$ & Very severe & 237.37 & 26.36 & 217.00 & 24.10 \\
\hline & $>200$ & Intense & 524.45 & 58.25 & 266.55 & 29.61 \\
\hline \multirow{6}{*}{ Río Laxaxalpan } & $<0.5$ & Normal & 6.99 & 0.43 & 32.90 & 2.05 \\
\hline & $0.5-5$ & Light & 36.26 & 2.26 & 243.01 & 15.12 \\
\hline & $5-15$ & Moderate & 68.87 & 4.28 & 268.19 & 16.68 \\
\hline & $15-50$ & Severe & 183.85 & 11.43 & 258.34 & 16.07 \\
\hline & $50-200$ & Very severe & 458.52 & 28.52 & 385.74 & 24.00 \\
\hline & $>200$ & Intense & 853.41 & 53.08 & 419.36 & 26.09 \\
\hline
\end{tabular}


In order to analyze the current erosion of the Necaxa River sub-basin, we observed an intense erosion with a soil loss higher than $200 \mathrm{t} \mathrm{ha}^{-1}$ per year in an area of $266.55 \mathrm{~km}^{2}$ (29.61\%). If the current handling remains unmodified, the potential erosion will increase, reaching an area of $524.45 \mathrm{~km}^{2}$ (58.25\%): a surface increase of $28.64 \%$ (Table 2).

Finally, in order to analyze the current erosion of the Laxaxalpan River sub-basin, we observed an intense erosion with a soil loss higher than $200 \mathrm{tha}^{-1}$ per year in an area of $419.36 \mathrm{~km}^{2}$ (26.09\%). If the current handling remains unmodified, the potential erosion will increase, reaching an area of $853.41 \mathrm{~km}^{2}$ (53.08\%): a surface increase of $26.99 \%$ (Table 2).

The Necaxa system does not include all the sub-basins (Figure 8 and 9); therefore, the solution proposed only apply to those sub-basins located in the north side, not to the whole system (Figures 10 and 11). Figure 11 shows that the greatest surface of current erosion is located in the low parts of the basin, as a result of the topographic slopes and the rainfed agriculture areas.

After calculating the current erosion of the San Marcos sub-basin of the Necaxa system, we observed an intense erosion with a soil loss higher than $200 \mathrm{tha}^{-1}$ per year in an area of $18.93 \mathrm{~km}^{2}(33.16 \%)$. If the current handling remains unmodified, the potential erosion will increase, reaching an area of $43.69 \mathrm{~km}^{2}(76.48 \%)$ : a surface increase of 43.32\% (Table 3).

Regarding the current erosion of the Necaxa River sub-basin of the Necaxa system, we observed an intense erosion with a soil loss higher than $200 \mathrm{t} \mathrm{ha}^{-1}$ per year in an area of $120.75 \mathrm{~km}^{2}$ (27.07\%). If the current handling remains unmodified, the potential erosion will increase, reaching an area of $274.00 \mathrm{~km}^{2}(61.42 \%)$ : a surface increase of $34.35 \%$ (Table 3).

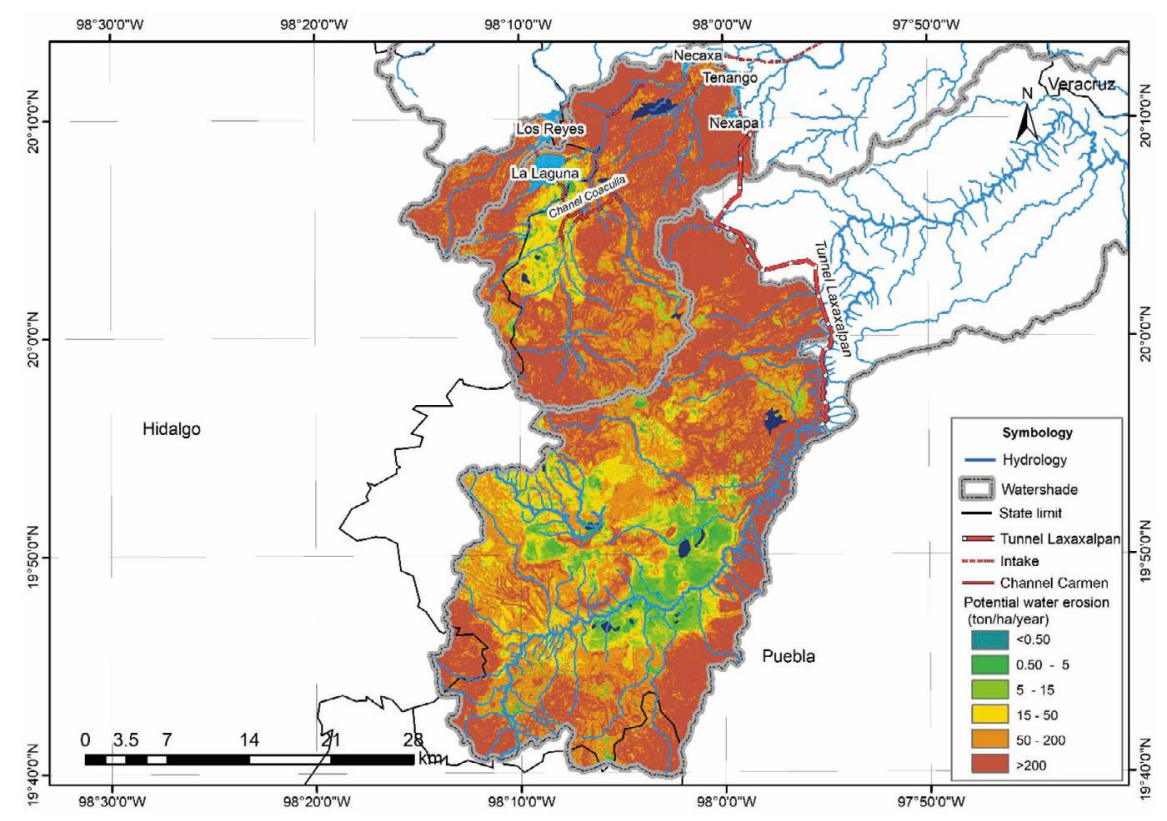

Figure 10. Potential erosion in the Necaxa system. 


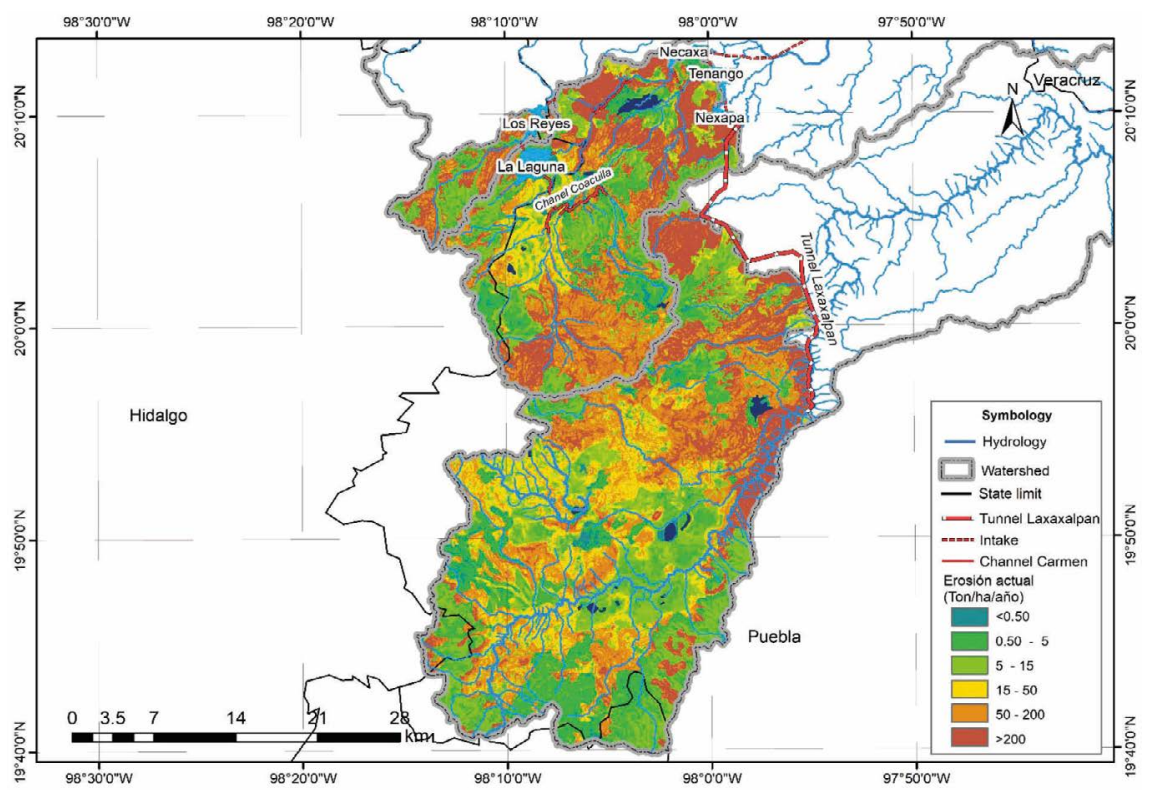

Figure 11. Current erosion in the Necaxa system.

Finally, regarding the current erosion of the Laxaxalpan River sub-basin of the Necaxa system, we observed an intense erosion with a soil loss ranging from 50 to $200 \mathrm{t} \mathrm{ha}^{-1}$ per year in an area of $190.91 \mathrm{~km}^{2}(21.40 \%)$. If the current handling remains unmodified, the

Table 3. Potential and current erosion in the sub-basins of the Necaxa system.

\begin{tabular}{|c|c|c|c|c|c|c|}
\hline \multirow{2}{*}{ Sub-basins } & \multirow{2}{*}{$\begin{array}{c}\text { Erosion range } \\
\text { t ha }^{-1} \text { year }\end{array}$} & \multirow{2}{*}{ Class } & \multicolumn{2}{|c|}{ Potential erosion area } & \multicolumn{2}{|c|}{ Current erosion area } \\
\hline & & & $\mathbf{k m}^{2}$ & $\%$ & $\mathbf{k m}^{2}$ & $\%$ \\
\hline \multirow{6}{*}{ Río San Marcos } & $<0.5$ & Normal & 0.25 & 0.43 & 0.56 & 0.98 \\
\hline & $0.5-5$ & Light & 0.01 & 0.02 & 9.92 & 17.37 \\
\hline & $5-15$ & Moderate & 0.56 & 0.98 & 13.86 & 24.28 \\
\hline & $15-50$ & Severe & 0.63 & 1.09 & 1.40 & 2.46 \\
\hline & $50-200$ & Very severe & 12.00 & 21.00 & 12.42 & 21.76 \\
\hline & $>200$ & Intense & 43.69 & 76.48 & 18.93 & 33.16 \\
\hline \multirow{6}{*}{ Río Necaxa } & $<0.5$ & Normal & 11.07 & 2.48 & 19.43 & 4.36 \\
\hline & $0.5-5$ & Light & 5.69 & 1.28 & 81.67 & 18.31 \\
\hline & $5-15$ & Moderate & 10.33 & 2.32 & 76.27 & 17.10 \\
\hline & $15-50$ & Severe & 36.78 & 8.24 & 52.19 & 11.70 \\
\hline & $50-200$ & Very severe & 108.24 & 24.26 & 95.74 & 21.46 \\
\hline & $>200$ & Intense & 274.00 & 61.42 & 120.75 & 27.07 \\
\hline \multirow{6}{*}{ Río Laxaxalpan } & $<0.5$ & Normal & 5.95 & 0.67 & 21.52 & 2.41 \\
\hline & $0.5-5$ & Light & 31.92 & 3.58 & 180.05 & 20.18 \\
\hline & $5-15$ & Moderate & 59.67 & 6.69 & 181.91 & 20.39 \\
\hline & $15-50$ & Severe & 135.42 & 15.18 & 160.34 & 17.97 \\
\hline & $50-200$ & Very severe & 277.14 & 31.06 & 190.91 & 21.40 \\
\hline & $>200$ & Intense & 382.16 & 42.83 & 157.34 & 17.64 \\
\hline
\end{tabular}


potential erosion will increase, reaching an area of $382.16 \mathrm{~km}^{2}(21.43 \%)$ : a surface increase of $26.99 \%$ (Table 3 ).

Overall, the Necaxa system reports a current average erosion of $159 \mathrm{t} \mathrm{ha}^{-1}$ per year, which indicates an erosion increase of $183 \%$, as a result of the lack of appropriate soil surface and vegetation handling. Unless appropriate handling activities are carried out in the basin, the siltation of the dams will continue.

As an alternative solution to the siltation problems of the water bodies and the hydraulic infrastructure, actions that strengthen the protection of natural resources must be proposed. These measures must be based on modifications to the $\mathrm{C}$ - and $\mathrm{P}$ - parameters, through reforestation measures and mechanical agricultural practices (Figure 12).

A conservation proposal for the edaphic resources of the Necaxa River system includes reforesting $214 \mathrm{~km}^{2}$ of pine-oak forests in zones that currently hold secondary vegetation. Additionally, agricultural management practices based on conservation agriculture have been proposed: leaving approximately $30 \%$ of the harvest waste on the soil surface, planting crops on the contour of the plot, and implementing terraces. All these measures should be carried out on of the three sub-basins $\left(704 \mathrm{~km}^{2}\right)$ of the Necaxa system under study, consequently allowing a decrease in the erosion problem (Table 4).

A reduction of the moderate erosion has been reported as a result of the measures proposed for the San Marcos sub-basin of the Necaxa System: 5-15 ha ${ }^{-1}$ per year in a $22.34 \mathrm{~km}^{2}$ area (39.15\%). Meanwhile, a reduction of the light erosion has been reported as a result of the measures proposed for the Necaxa sub-basin of the Necaxa system: 0.5-5 $\mathrm{ha}^{-1}$ per year in a $163.74 \mathrm{~km}^{2}$ area $(36.72 \%)$.

Finally, reduction of the light erosion has been reported as a result of the measures proposed for the Laxaxalpan sub-basin of the Necaxa system: $0.5-5 \mathrm{ha}^{-1}$ per year in a

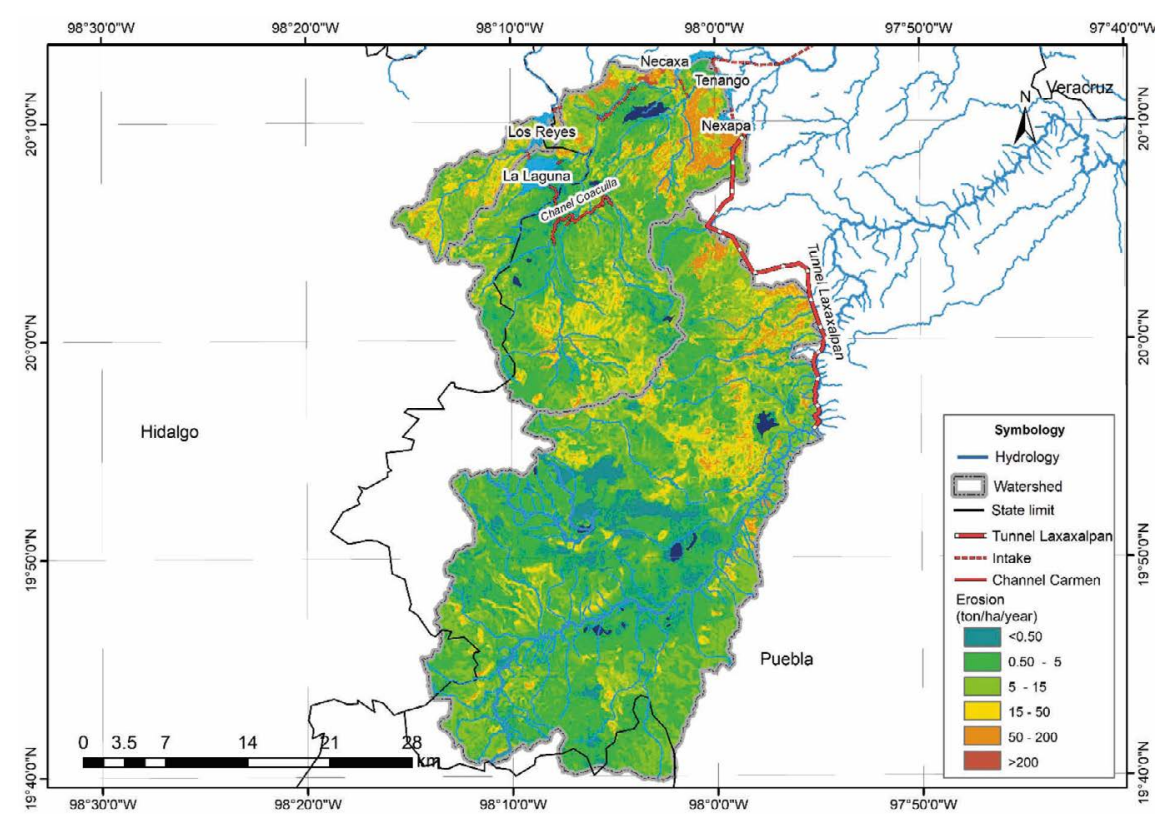

Figure 12. Solution option based on basin management practices. 
Table 4. Solution options to avoid an increase in the siltation of the Necaxa system.

\begin{tabular}{|c|c|c|c|c|}
\hline \multirow{2}{*}{ Sub-basins } & \multirow{2}{*}{$\begin{array}{l}\text { Erosion range } \\
\text { t ha }^{-1} \text { por año }\end{array}$} & \multirow{2}{*}{ Class } & \multicolumn{2}{|c|}{ Area } \\
\hline & & & $\mathbf{k m}^{2}$ & $\%$ \\
\hline \multirow{6}{*}{ Río San Marcos } & $<0.5$ & Normal & 0.90 & 1.57 \\
\hline & $0.5-5$ & Light & 10.88 & 19.07 \\
\hline & $5-15$ & Moderate & 22.34 & 39.15 \\
\hline & $15-50$ & Severe & 18.42 & 32.28 \\
\hline & $50-200$ & Very severe & 4.36 & 7.64 \\
\hline & $>200$ & Intense & 0.17 & 0.29 \\
\hline \multirow{6}{*}{ Río Necaxa } & $<0.5$ & Normal & 30.50 & 6.84 \\
\hline & $0.5-5$ & Light & 163.74 & 36.72 \\
\hline & $5-15$ & Moderate & 137.94 & 30.93 \\
\hline & $15-50$ & Severe & 73.99 & 16.59 \\
\hline & $50-200$ & Very severe & 36.48 & 8.18 \\
\hline & $>200$ & Intense & 3.32 & 0.74 \\
\hline \multirow{6}{*}{ Río Laxaxalpan } & $<0.5$ & Normal & 98.50 & 11.05 \\
\hline & $0.5-5$ & Light & 413.72 & 46.39 \\
\hline & $5-15$ & Moderate & 254.47 & 28.53 \\
\hline & $15-50$ & Severe & 94.71 & 10.62 \\
\hline & $50-200$ & Very severe & 28.98 & 3.25 \\
\hline & $>200$ & Intense & 1.40 & 0.16 \\
\hline
\end{tabular}

$413.72 \mathrm{~km}^{2}$ area (46.39\%). The proposed measures aim to achieve a tenfold reduction of erosion with regard to the current situation: i.e., reducing the current 159 ton/ha*year erosion to an average of 0.5 (light) to 15 (moderate) $\mathrm{t} \mathrm{ha}^{-1}$ per year. This measure would guarantee a longer useful life for the Necaxa system.

\section{GONGLUSIONS}

This study about the current and potential erosion shows that reforestation measures and conservation agricultural practices would cut down erosion in the Necaxa system from the current annual average of $159 \mathrm{t} \mathrm{ha}^{-1}$ to $0.5-15 \mathrm{t} \mathrm{ha}^{-1}$ per year. This study also proposes possible solutions based on the basin management, applying the USLE through the Geographical Information Systems. Otherwise, if no action is carried out, erosion could exceed $200 \mathrm{t} \mathrm{ha}^{-1}$ per year, which would worsen siltation problems in water bodies and infrastructure; additionally, soils will lose their productivity and the ecosystem will face adverse changes.

\section{REFERENGES}

África Dumas, S. (2012). Riesgo de erosión hídrica en la cuenca hidrográfica del río Mundo. La Universidad Complutense de Madrid.

Alatorre, L. C., García, A. K., Rodríguez, A. J., Erives, V., \& González, E. (2014). Estimación de la erosión potencial en la cuenca de la Laguna Bustillos, Chihuahua, México. In: Garcia Ruiz, J.M., Geoecología, cambio ambiental y paisaje, 249-258. Consejo Superior de Investigaciones Científicas, Ernestina M. del Puerto, Santa Cecilia, Tláhuac, 13010 Ciudad de México, CDMX. 
Alejandrina, M., León, M., Domínguez, M. A., \& Ventura, E. (2013). Metodología para la estimación del riesgo de erosión hídrica en cuencas hidrográficas utilizando un SIG. Maestría en Hidráulica. Facultad de Ingeniería-División del Posgrado, UniversidadAutonoma de Queretaro, C.U: Cerro de las Campanas, Queretaro, Qro. 76010

Bonilla, C. A., Reyes, J. L., \& Magri, A. (2010). Water erosion prediction using the revised universal soil loss equation (RUSLE) in a gis framework, central Chile. Chilean journal of agricultural research, $70(1)$, 159-169. Doi: 10.4067/S0718-58392010000100017.

Colín-García, G., Ibáñez-Castillo, L. A., Reyes-Sánchez, J., \& Arteaga-Ramírez, R. (2013). Diagnóstico de La Erosión Hídrica de la Guenca del Río Pichucalco. Ingeniería Agrícola y Biosistemas, 5(1), 23-31. Doi: 10.5154/r.inagbi.2013.04.002

Díaz R, J. (2015). Diagnóstico del potencial de erosión hídrica mediante técnicas de geoprocesamiento en la sub-cuenca del río Angasmarca, La Libertad, Perú. Anales Científicos, 76(2), 283-293. Doi: 10.21704/ ac.v76i2.793

Durán Trejo, S. (2012). Riesgo a la erosión hídrica y práctica de manejo de suelos en la microcuenca La Concodia, Armadillo de los Infantes, S.L.P. Universidad Autónoma de San Luis Potosí.

ESRI. (2016). ArcGIS Desktop: Release 10.4. En Redlands CA. Environmental Systems Resource Institute.

FAO, O. de las N. U. para la A. y la A. (2015). Base referencial mundial del recurso suelo 2014. Sistema internacional de clasificación de suelos para la nomenclatura de suelos y la creación de leyendas de mapas de suelos (FAO, Organ). publications-sales@fao.org.

Flores-López, H. E., Martínez-Menes, M., Oropeza-Mota, J. L., Mejía-Saenz, E., \& Carrillo-González, R. (2002). Integración de la EUPS a un SIG para estimar la erosión hídrica del suelo en una cuenca hidrográfica de Tepatitlán, Jalisco, México. Terra Latinoamericana E-ISSN:21, 233-244.

Flores Islas, E. (2016). Estimación de la pérdida de suelo por erosión hídrica en tres subcuencas de la República Mexicana, utilizando la ecuación universal de pérdida de suelo. Universidad Nacional Autónoma de México.

INEGI. (2013). Continuo de Elevaciones Mexicano 3.0 (CEM 3.0). Instituto Nacional de Estadística y Geografía. Disponible en: http://www.inegi.org.mx/geo/contenidos/datosrelieve/continental/ continuoelevaciones.aspx

INEGI, I. N. de E. y G. (2003). Conjunto de datos vectoriales de la carta de Uso de Suelo y Vegetación. Escala 1:250,000. Serie III. Instituto Nacional de Estadística y Geografía.

INEGI, I. N. de E. y G. (2007). Conjunto de datos vectoriales Edafológicos. Escala 1:250,000. Serie II (Continuo Nacional). Instituto Nacional de Estadística y Geografía.

Jiménez Callejo, L., Martínez De Anguita, P., Ángeles Ruiz, M., Dunin-borkowski, S. M., \& Guerrero, D. (2008). Metodología para la zonificación del riesgo de erosión en cuencas Andinas. Estudio de caso en el río Chalaco, Piura. Uned. Espacio, Tiempo y Forma, VI (1), 11-32. Doi: 10.5944/etfvi.1.2008.1456

Laval Molkenbuhr, E. (2009). Determinación de erosión actual y fragilidad de suelos en la V Región utilizando datos satelitales y SIG.

López-Santos, A., Sánchez Cohen, I., Esquivel Arriaga, G., \& González Barrios, J. L. (2012). Evaluación de la vulnerabilidad de los suelos del estado de Durango, México en el contexto del cambio climático. Agrociencia, 16(3), 117-127.

Lozano-García, B., \& Parras-Alcántara, L. (2011). Erosión actual y potencial en suelos ácidos del sur de España. Terra Latinoamericana, 29(1), 35-46.

Luna Lemus, M. F. (2016). Determinación de la erosión hídrica y la producción de sedimentos en la cuenca del río Pixcayá aplicando herramientas SIG, Tesis de maestria. Universidad del Valle de Guatemala. 18 Av. 11-95 Guatemala, 01015, Guatemala. 105-117.

Melchor-Marroquín, J. I., \& Chagoya-Fuentes, J. L. (2016). Diagnóstico de la erosión hídrica en la cuenca del río Tuxpan, Veracruz, México. Aqua-LAC, 8(2), 25-35. Doi: 10.29104/phi-aqualac/2016-v8-2-03

Montes-león, M. A. L., Uribe-Alcántara, E. M., \& García-Celis, E. (2011). Mapa Nacional de Erosión Potencial. Tecnología y Ciencias del Agua, 2(1), 5-17.

Muñoz-Marcillo, J. L., Morante-Carriel, J., \& Miranda-Ullón, P. (2014). Erosión potencial por reconversión productiva en subcuenca Llay-Llay, Chile. Aplicación de unidades de respuesta a la erosión. Ciencia y Tecnología, 7(2), 35-47.

Olmos, L. A., Spalleti, P., Farias, H. D., \& Pilán, M. T. (2008). Verificación de modelos de producción de sedimentos en cuencas del N.O. Argentino. Ingeniería del Agua, 15(2), 1134-2196. Doi: 10.4995/ ia.2008.2926

Pacheco Gil, H. A. (2012). El índice de erosión potencial en la vertiente norte del Waraira Repano, estado Vargas, Venezuela. Revista colombiana de geografía. 21(2), 85-97. 
Pedraza Villafaña, A. (2015). Estimación de la erosión hídrica mediante dos métodos de la Ecuación Universal de Pérdida de Suelo (EUPS) en la cuenca del río Chapingo, Texcoco. Universidad Autónoma del Estado de México.

Pizarro, R., Moralez, C., Vega, L., Olivares, C., Rodrigo, V., \& Balocchi, F. (2009). Propuesta de un modelo de estimación de la erosión hídrica para la región de Coquimbo, Chile (Documentos Técnicos del PHI-LAC, No. 18).

Portuguez M., D. M. (2015). Estimación de la pérdida de suelos por erosión hídrica en la cuenca del río Siguas utilizando geoinformática. Anales Científicos, 76(2), 324-329. Doi: 10.21704/ac.v76i2.797

Rodríguez-Vagaría, A., \& Gaspari, F. (2015). Estimación de la admisibilidad de pérdidas de suelo por erosión hídrica en la cuenca del arroyo Napaleofú , provincia de Buenos Aires-Argentina. Revista Geográfica Venezolana, 56(1), 105-119.

Saldaña Días, M. M., Nemmaoui, A., Cantón Castilla, M. Y., Aguilar Torres, M. A., \& Aguilar Torres, F. A. (2014). Estimación de la erosión potencial en la cuenca del río Moulouya aguas arriba de la presa Mohamed V. Mapping, 23(168), 4-16.

SMN. (2017). Estaciones Climatológicas 2016. Servicio Meteorológico Nacional. Disponible en: http://smn. cna.gob.mx/tools/RESOURCES/estacion/EstacionesClimatologicas.kmz

SRH. (1969). Boletín hidrológico 42. Región hidrológica 27 (Tuxpan-Nautla). Disponible en: http://hidrosuperf. imta.mx/pronacch/Boletines/42/tomo 1/Boletín 42 Tomo 1.pdf

Stefanidis, S., Ghatzichristaki, G., \& Stefanidis, P. (2017). Development of a GIS toolbox for automated estimation of soil erosion. Environmental Impact Assessment and Risk Analysis, June, 665-673.

Torres Benites, E., Cortes Becerra, J., Mejía Sáenz, E., Exebio García, A., Santos Hernández, A. L., \& Delgadillo Piñón, M. E. (2003). Evaluación de la degradación de los suelos en la cuenca "El Josefino", Jesús María, Jalisco. Terra Latinoamericana, 21(1), 117-126.

UNESCO - PHI. (2017). Evaluación de la degradación de suelos en el estado de puebla, México. En Procesos de erosión. Sedimentación en cauces y cuencas. (Número III, pp. 80-96). United Nations Educational, Scientific and Cultural Organization. Disponible en: http://eias.utalca.cl/isi/publicaciones/erosion_y_ sedimentacion_voll.pdf

Wischmeier, W. H., \& Smith, D. D. (1978). Predicting rainfall erosion losses a guide to conservation planning (Número 537). U.S. Department of Agriculture, Agriculture Handbook no. 537.

Zavala-Cruz, J., Palma-López, D. J., Fernández Cabrera, C. R., López Castañeda, A., \& Shirma Tórres, E. (2011). Degradación y conservación de suelos en la cuenca del río Grijalva, Tabasco. Colegio de Postgraduados, Secretaría de Recursos Naturales y Protección Ambiental y PEMEX. 